\title{
GCA Squared
}

Michael Rasminsky, MD, PhD

Neurolog $y^{\circledR}$ 2021;97:90-91. doi:10.1212/WNL.0000000000011924
Correspondence

Dr. Rasminsky

michael.rasminsky@

mcgill.ca
The bizarre coincidence (or is it a coincidence?) through which my wife and I are now living illustrates many of the physician pitfalls of diagnosing one's own family and the subsequent perils or rewards of knowing too much.

For several weeks my healthy 80 -year-old wife complained bitterly of nasal stuffiness, then less insistently of fatiguing of her jaw, which I blithely ignored until she began to have some very mild headaches and more generalized weakness on our daily walk/escape from COVID house arrest. After unrewarding ENT and dental consultations, the penny finally dropped; being de facto inappropriately in charge of her care, I arranged for her to have bloodwork that showed sky high inflammatory markers. Our internist and I agreed that this was probably giant cell arteritis (GCA) and I immediately fed my wife a stash of prednisone languishing in my medicine chest after my own long-resolved episode of gout. Temporal artery biopsy the following day proved the diagnosis of GCA and she is now well launched on a tapering course of prednisone.

I spent the next 2 weeks beating myself up for failing to make the diagnosis more promptly, distracted as I was by the probably irrelevant nasal stuffiness that dominated the original picture.

As my agitation about missing the diagnosis subsided, I began myself to experience daily episodes of vertical diplopia after walking a mile or so. As a neurologist, I had no difficulty in attributing these episodes to transient weakness of the right superior rectus muscle. My first thought was that this might reflect old man's (age 82) ocular myasthenia, but consultation with one of my neurologist pals showed a totally normal neurologic exam, and blood drawn for ACh receptor antibodies came back negative.

Some days later I began to experience recurrent visual symptoms-a grayish immobile scotoma lasting about 10 minutes in my right eye, and an almost complete loss of vision within a full shining bright field punctuated with small islands of normal vision in my left eye lasting 2 or 3 minutes, in neither case typical of the usual symptoms of amaurosis fugax. I am a long-time migraineur and have several episodes a year of visual migraine auras without headache, invariably involving both eyes symmetrically. But this was completely different. These new symptoms of intermittent diplopia and monocular visual loss pointed to mischief within my orbits. The implication that either the optic nerves or the retinas were involved elicited much more anxiety and raised the seemingly absurd question as to whether I too could have GCA and be heading for the dreaded complication of blindness.

My ophthalmologist proclaimed my eyes normal but expressed appropriate concern and directed me to one of my cerebrovascular disease colleagues, who in turn sent me down the rabbit hole of a Holter monitor and a full cardiovascular workup that showed a heart and carotid arteries of praiseworthy quality.

Still free of headache or systemic symptoms, I nonetheless began to suspect that I too had some jaw claudication. Was this late-onset hypochondria in an individual who has never somatized? Was this symptom in sympathy with my partner of more than 50 years?

It couldn't be: as the next few days wore on, the reality of the jaw claudication became inescapable. My inflammatory blood markers were modestly elevated. With this new information and my ophthalmologist now pushing hard for the diagnosis of GCA, I co-opted some of my wife's new stash of prednisone to begin preemptive treatment. A temporal artery biopsy came back, showing 
inflammation consistent with GCA, which was then fortified by ultrasound findings of a diagnostic halo $\operatorname{sign}^{1}$ in my surviving temporal artery and some indication of swelling in the vasculature to my jaw.

So my wife and I are now in lock step with our matching his and hers temporal artery biopsy scars, one following the other on a hopefully downward trajectory of steroid consumption. My various docs-friends and colleagues, ophthalmologists, internists, neurologists, rheumatologists-are all intrigued with the question of whether there is some causal relationship such as a viral infection prompting this unusual coincidence despite the interval of several weeks between the onset of our respective symptoms, or whether this is simply another bit of anecdotal weirdness to further clutter the medical literature. ${ }^{2,3}$

There is an interesting statistical fallacy here. The Mayo Clinic notes that the incidence of GCA in 80+-year-old males is $28.5 / 100,000$, while the female incidence is $103.8 / 100,000{ }^{4}$ At first glance, this would appear to predict that the chances of a random pair both getting GCA-a noncommunicable disease - in the same year would be roughly 3 in 10 million.

But it gets more interesting: according to Statistics Canada, ${ }^{5}$ the number of males in the 80- to 89-year-old age group is about 568,000; the number of females, about 760,000. At a rough guess, there might be 300,000 Canadian couples in this age cohort. If the chances of a couple of this age both getting GCA is indeed 3 in 10 million, the number of conjugal occurrences per year would be predicted to be $3 / 10,000,000 \times$ $300,000 \cong 0.09$. In other words, the appearance of a couple in the $80+$ cohort coincident for GCA could be predicted to be a once in a decade event in Canada: rare but not a once in a lifetime occurrence.

It is fun to play with numbers; nonetheless, my wife's diagnosis does not statistically immunize me-my chances of getting GCA would still be roughly 3 in 10,000, improbable but not inconceivable. The last word goes to the great detective Sherlock Holmes: "When you have excluded the impossible, whatever remains, however improbable, must be the truth."

\section{References}

1. Schmidt WA, Kraft HE, Vorpahl K, Völker L, Gromnica-Ihle EJ. Color duplex ultrasonography in the diagnosis of temporal arteritis. N Engl J Med 1997;337: 1336-1342.

2. Barrier JH, Brisseau JM, Lucas V, Maugard-Louboutin C, Groleau J, Grolleau JY. Giant cell arteritis in a conjugal pair. J Rheumatol 1988;15:383-384.

3. Galetta SL, Raps EC, Wulc AE, et al. Conjugal temporal arteritis. Neurology 1990;40: 1839-1842.

4. Kermani TA, Schäfer VS, Crowson CS, et al. Increase in age at onset of giant cell arteritis: a population-based study. Ann Rheum Dis 2010;69:780-781.

5. Statistics Canada. Demographic Estimates by Age and Sex, Provinces and Territories. Available at: 150.statcan.gc.ca/n1/pub/71-607-x/71-607-x2020018-eng.htm 


\title{
Neurology
}

\author{
GCA Squared \\ Michael Rasminsky \\ Neurology 2021;97;90-91 Published Online before print April 15, 2021 \\ DOI 10.1212/WNL.0000000000011924
}

This information is current as of April 15, 2021

Updated Information \& Services

References

Subspecialty Collections

Permissions \& Licensing

Reprints including high resolution figures, can be found at: http://n.neurology.org/content/97/2/90.full

This article cites 4 articles, 2 of which you can access for free at: http://n.neurology.org/content/97/2/90.full\#ref-list-1

This article, along with others on similar topics, appears in the following collection(s):

Diplopia (double vision)

http://n.neurology.org/cgi/collection/diplopia_double_vision Visual loss

http://n.neurology.org/cgi/collection/visual_loss

Information about reproducing this article in parts (figures,tables) or in its entirety can be found online at:

http://www.neurology.org/about/about_the_journal\#permissions

Information about ordering reprints can be found online:

http://n.neurology.org/subscribers/advertise

Neurology ${ }^{\circledR}$ is the official journal of the American Academy of Neurology. Published continuously since 1951, it is now a weekly with 48 issues per year. Copyright (C 2021 American Academy of Neurology. All rights reserved. Print ISSN: 0028-3878. Online ISSN: 1526-632X.

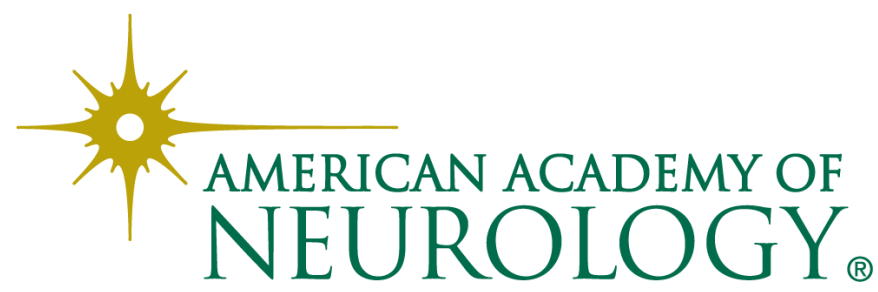

